\title{
DOE/OR/DKOS $89-2$
}

U.S. DEPARTMENT OF THE INTERIOR U.S. GEOLOGICAL SURVEY

\section{OCT 261993 \\ OSTI}

ANNOTATED BIBLIOGRAPHY

HYDROGEOLOGY OF KIIAAUEA VOLCANO, HAWAII

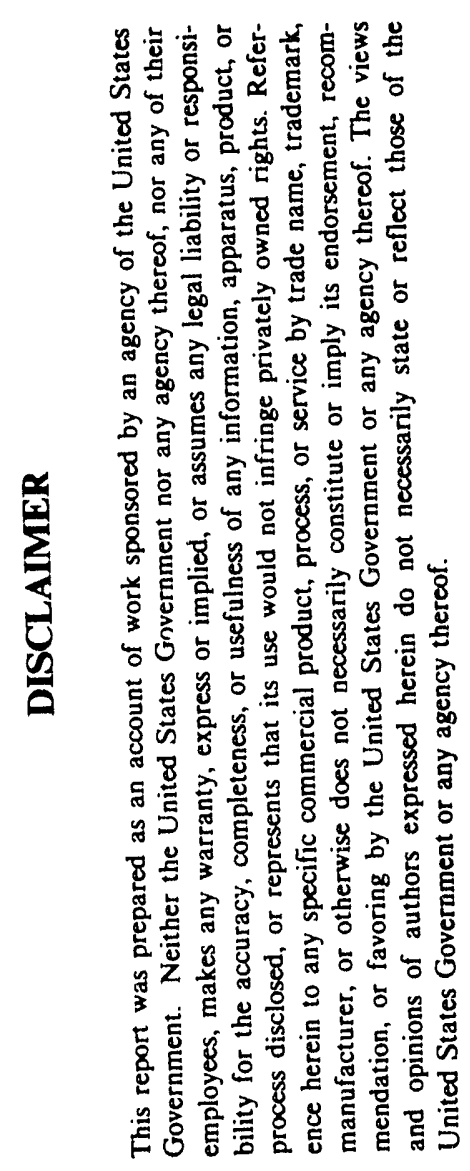

By

S.E. Ingebritsen and M.A. Scholl ${ }^{1}$

Open-File Report 93-551-D

Prepared in cooperation with the

U.S. Department of Energy

This report is preliminary and has not been reviewed for conformity with U.S. Geological Survey editorial standards (or with the North American Stratigraphic Code). Any use of trade, product, or firm names is for descriptive purposes only and does not imply endorsement by the U.S. Geological Survey.

1. Menlo Park, California 94025

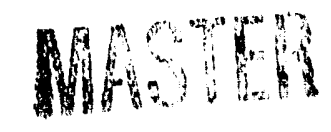


General hydrogeology $\ldots \ldots \ldots \ldots \ldots \ldots \ldots \ldots \ldots \ldots \ldots \ldots \ldots \ldots$

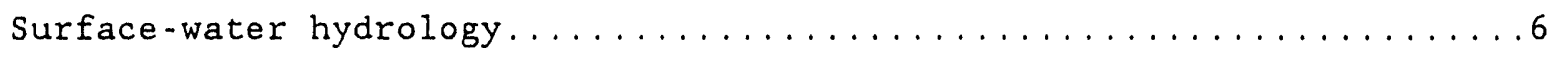

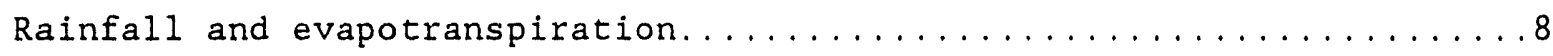

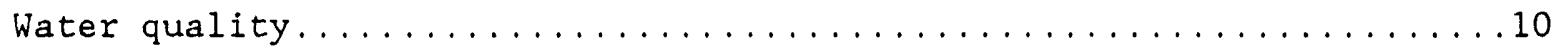

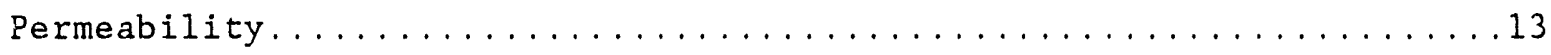

Hydrothermal systems/hydrothermal modeling ...............

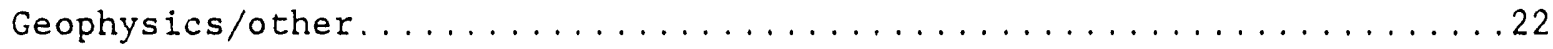

References.................................... 


\section{LIST OF ILLUSTRATIONS}

$\underline{\text { Page }}$

Fig. 1 Cross section of an idealized volcanic island showing occurrence and recovery of ground water...............

Fig. 2 Well locations and relative spring-discharge temperatures.....5

Fig. 3 Average annual rainfall and pan evaporation.............9

Fig. 4 Conceptual model of shallow magma reservoirs and associated hydrothermal systems beneath Mauna Loa and Kilauea volcanoes............................16 


\section{GENERAL HYDROGEOLOGY}

Davis, D.A., and Yamanaga, George, 1966, Preliminary report on the water resources of the Kau District, Hawail: Hawail Division of Water and Land Development, Dept. of Land and Natural Resources Circular C27, 25 p.

Davis, D.A., and Yamanaga, George, 1968, Preliminary report on the water resources of the Hilo-Puna area, Hawail: Hawaii Division of Water and Land Development, Dept. of Land and Natural Resources Circular C45, 38 p.

Davis, D.A., and Yamanaga, George, 1973, Water resources summary Island of Hawai1: Hawaif Division of Water and Land Development, Dept. of Land and Natural Resources Report R47, $42 \mathrm{p}$.

The 1966 Kau District report includes descriptive summaries of the geology, rainfall, streamflow, and ground-water occurrence. The authors (p. 23) describe high-level ( $70 \mathrm{~m}$ above sea level) ground water in the Pahala area, impounded by "some undetermined structural feature".

The 1968 Hilo-Puna report includes similar descriptive material plus information from wells drilled between 1944-1967 and a fairly detailed summary of streamflow records published by the USGS. The authors ( $p .30$ ) stated that dikes in Kilauea's lower east-rift zone appear to form a barrier to southward movement of ground water: basal ground water south of the rift zone is generally warmer and more saline than that to the north.

The 1973 Island of Hawai report summarizes previous water-resources work on an island-wide basis. It includes a $1: 200,000$ scale map showing streamflowgaging stations, ground-water occurrence (perched, impounded, and basal), and wells, with information on depths, water levels, and salinity. Also includes ( $p .9-15$ ) a list of 81 gaging stations; a useful, general overview of basal ground water (p. 29-37); and drawdown/specific capacity data for 10 wells ( $p .33$ ), including 3 in rocks of Kilauea volcano.

Druecker, Michael, and Fan, P.-F., 1976, Hydrology and chemistry of ground water in Puna, Hawail: Ground Water, v. 14, p. 328-338.

Includes maps of chloride and silica concentrations in ground water and ground-water temperature prepared on the basis of data from 32 wells and shafts. In other respects description and interpretation of the hydrogeology relied heavily on Davis and Yamanaga (1968). The authors agreed that the east-rift zone is an effective barrier to ground-water movement, mentioning a difference in basal water-table elevation across the rift zone ( $p .332$ ). 
Hawa11 Department of Land and Natural Resources, 1970, An inventory of basic water resources data, Island of Hawail: Division of Water and Land Development Report R34, $188 \mathrm{p}$.

Includes basic data on rainfall (p. 12-78), evaporation (p. 103-109), streamflow ( $p .123-137$ ), wells ( $p .141-156$ ), shafts and tunnels ( $p .157$ 173), springs ( $p .174-180$ ) and water quality ( $p .181-188$ ).

Hunt, C.D., Jr., Ewart, C.J., and Voss, C.I., 1988, Region 27, Hawailan Islands in Back, William, Rosenshein, J.S., and Seaber, P.R., eds., The Geology of North America, v. 0-2, Hydrogeology: Boulder, Geological Soclety of America, p. 255-262.

Brief, general introduction to hydrogeology of Hawailan Islands.

Ingebritsen, S.E., and Scholl, M.A., 1993, The hydrogeology of K1lauea volcano: Geothermics, in press.

A review paper with sections on basal, perched, and dike-impounded water; patterns and rates of ground-water flow; permeabilities; and hydrothermal modeling.
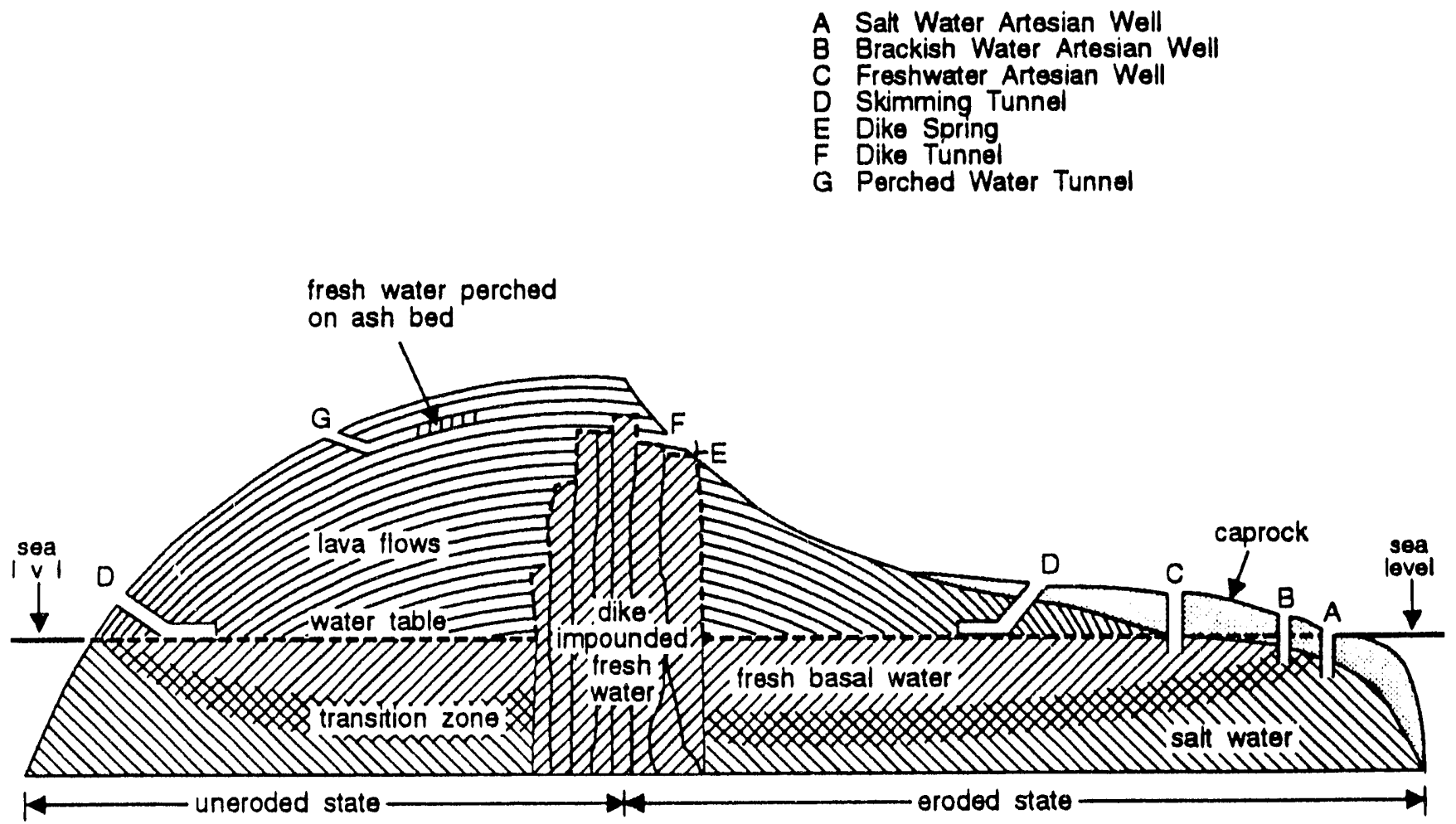

Fig. 1 Cross section of an idealized volcanic island showing occurrence and recovery of ground water (after Peterson, 1981, Fig. 4). 
Peterson, F.L., 1981, Geological and hydrological framework: A history of development in Fujimura, F.N., and Chang, W.B.C., eds., Groundwater in Hawail: A century of progress: University of Hawaii at Manoa, p. 114.

Another brief, general introductory paper. Cited an average water-table gradient of 0.0002 for the Hawaiian Islands. Includes the schematic diagram of ground-water occurrence shown as Figure 1 of this report.

Stearns, H.T., and Clark, W.0., 1930, Geology and water resources of the Kau District, Hawail: U.S. Geological Survey Water-Supply Paper 616, 194 p.

This is the first comprehensive report of hydrogeologic studies of Hawaii that began in 1920. Here O.E. Meinzer, head of the then Ground-Water Division of the U.S.G.S., summarized Hawaiian hydrology as follows:

"To a person who is familiar only with the mainland, the hydrologic conditions in the Hawaiian Islands seem to be freakish in every respect ... The rainfall differs from anything found on the mainland in both intensity and areal variability ... The islands consist of great volcanoes ... Generally speaking, the lava rock is like a sieve... The hydrologic consequences of the widepread occurrence of this very permeable rock are obvious rapid absorption and downward percolation of the rain water; small and flashy runoff; ... great ground-water recharge and large supply of ground water; very low and flat water table with great depths to ground water in most places; copious springs in the low valleys, along the coasts, and on the adjacent sea botton; and salt water at no great depth below the water table."

O.E. Meinzer, in Stearns and Clark (1930)

The tripartite classification of Hawaiian ground water as "basal," "perched," or "dike-impounded" was well-established by 1920, when O.E.

Meinzer visited Hawaii. The perching members are relatively impermeable ash layers or buried soils (e.g., O.E. Meinzer in Stearns and Clark, 1930, p. 21-23). The existence of "dike-impounded" water substantially above the basal level (Fig. 1) was first documented during construction of the Waiahole tunnel on Oahu in 1913-1915 (O.E. Meinzer, in Stearns and Clark, 1930, p. 23f). There, head differences of about 50 meters were measured across 1- to 4-m-thick dikes. Meinzer (in Stearns and Clark, 1930, p. 26) noted that the complexes of intersecting dikes that serve to impound ground water are found in rift zones along which magma has risen to feed eruptions.

Stearns and Clark (1930) also described historic and prehistoric phreatic eruptions ( $p .143 \mathrm{f}$ ) and related them to heated ground water ( $p$. 155f). They did not find any hot $\left(\geq 37{ }^{\circ} \mathrm{C}\right)$ springs in the Kau district, but listed occurrences of steam vents and warm water ( $p .190)$. 
Stearns, H.T., and MacDonald, G.A., 1946, Geology and ground-water resources of the Island of Hawali: Hawaii Division of Hydrography Bulletin 9 , $362 \mathrm{p}$.

Includes the first extensive water-chemistry data for the Island of Hawaii (p. 287f) and comprehensive inventories of sea-level springs ( $p .252 \mathrm{f}$, 261f), wells (p. 285f), perched springs (p. 290f) and tunnels (p. 254f, $263 f, 296 f)$. The data indicate that the total yield of visible springs, tunnels, and wells on Hawaii amounts to only about 2.5 percent of the rainfall, and the authors inferred that huge unmeasured amounts of water issue from springs at or below sea level. This conclusion is consistent with later thermal-infrared imagery of the Hawailan coastline (Fischer et al., 1966).

The authors ( $p .246$ ) cited an average water-table gradient of 0.001 for the. area north of Kilauea's east-rift zone and suggested ( $p$. 224-225) that concealed dikes in the interiors of Mauna Loa and Kilauea might impound ground water. The scarcity of hot springs was attributed to the high permeability of the volcanic rocks (p. 269).

Like Stearns and Clark (1930), most of this report (p. 13-208) is devoted to describing the geologic framework for the island's water resources. For example, it includes a detailed description of the Pahala Ash ( $p .68 f$ ), an important perching layer on the southeast flank of Mauna Loa. The islandwide geologic map of Stearns and MacDonald (1946) has only recently been superceded.

Takasaki, K.J., 1993, Ground-water occurrence in Kilauea Volcano and adjacent parts of Mauna Loa Volcano: U.S. Geological Survey Open-File Report 93-82, in press.

Intended as a general-interest publication, but includes information not readily obtained from other published work, including maps of water-table elevation, ground-water recharge rates, and well locations, and some watertemperature data. Existence of a relatively high-level water table in the upper east- and southwest-rift zones of Kilauea was inferred from electrical soundings that identified a continuous high-level low-resistivity layer extending from Kilauea summit down the east-and southwest-rift zones (Jackson and Kauahikaua, 1990). In other areas water-table elevations were obtained by direct measurement. The water-table configuration beneath Mauna Loa upslope of Kilauea summit is unknown. Total ground-water recharge on Kilauea and adjacent areas of Mauna Loa was estimated to be $150,000 \mathrm{~L} / \mathrm{s}$, or about 50-60 percent of total rainfall. There is substantial areal variation in recharge rates. Because surface runoff is negligible and actual evapotranspiration will not greatly exceed pan evaporation, recharge in the high-rainfall areas was estimated as the difference between rainfall and pan evaporation. In the highest-rainfall areas southeast of Hilo recharge rates estimated on this basis exceed $4 \mathrm{~m} / \mathrm{yr}$. In low-rainfall areas actual evapotranspiration is much less than pan evaporation, and rechar 5 cannot be estimated by a simple differencing. Recharge rates of $0.04-0.25$ 
$\mathrm{m} / \mathrm{yr}$ are suggested for areas where rainfall ranges from $0.5-1.5 \mathrm{~m} / \mathrm{yr}$. These values are consistent with those calculated by Giambellucca (1986) for the driest areas on Oahu.

Takasaki stated that Kilauea's rift zones act to compartmentalize the ground-water flow system, so that recharge on the south flank of Mauna Loa above Kilauea does not reach the area bounded by the east-and southwestrift zones of Kilauea and the ocean.

Takasaki, K.J., and Mink, J.K., 1985, Dike-impounded ground-water reservoirs, Island of Oahu: U.S. Geological Survey Water-Supply Paper $2217,77 \mathrm{p}$.

Includes a general description of dike impoundment. Dike intrusion reduces horizontal permeability in the direction normal to the dike plane. Where dikes are numerous and intersecting, overall horizontal permeability is substantially reduced ( $p, 7)$.

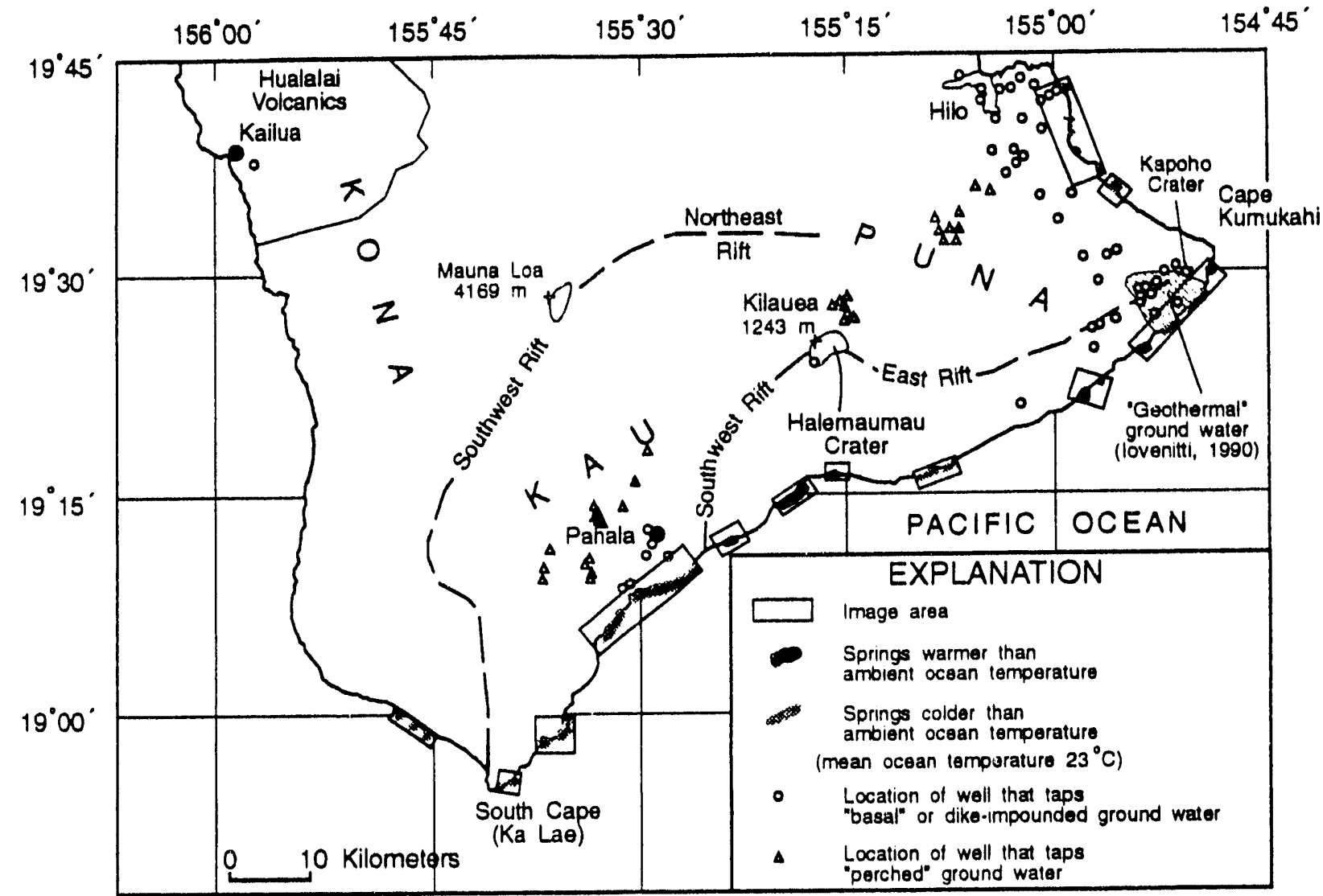

Fig. 2 Well locations (Takasaki, 1993) and relative spring-discharge temperatures (Fischer et al., 1966) in Kau, Puna, and South Hilo districts, Island of Hawail. 
Nearly all streams in the area bounded by the rift zones of Mauna Loa and the Pacific Ocean (Fig. 2) are ephemeral. However, considetable data are available regarding the discharge and water chemistry of springs and ephemeral streams.

Cha1, D.K., Cuddihy, L.W., and Stone, C.P., 1989, An inventory and assessment of anchialine pools in Hawail Volcanoes National Park from Waha'ula to Ka'aha, Puna and Ka'u, Hawal'i: Cooperative National Park Resources Study Unit, Department of Botany, University of Hawal'1, Technical Report 69, $37 \mathrm{p}$.

Anchialine pools are defined and described on p. 1:

"[they] are exposed portions of the groundwater table predominantly found on geologically young, porous lavas in the coastal tropics and subtropics. Although anchialine pools have no surface connection to the sea, they exhibit tidal fluctuation and contain water with measureable salinity, indicating a subsurface connection. Most anchialine pools support a unique biota ..."

There are approximately 169 anchialine ponds in " ... East Hawai'i from Leleiwi Point to South Point ..."

Many of the features described by earlier workers as ponds, cracks, or water holes fit this definition of anchialine ponds.

Fischer, W.A., Davis, D.A., and Sousa, T.M., 1966, Fresh-water springs of Hawali from infrared images: U.S. Geological Survey Hydrologic Investigations Atlas HA-218.

The areas for which infrared measurements were made show ubiquitous, plumelike thermal anomalies extending into the ocean (Fig. 2). These anomalies are presumably caused by ground-water discharge. Although no hot springs have been reported to the south of the southwest-rift zone of Kilauea, the thermal imagery (Fig. 2) documents relatively warm spring-discharge temperatures along the shoreline below both the southwest-and east-rift zones. Outside the area bounded by the rift zones, spring temperatures are generally lower than the ambient ocean temperature. An apparent resistivity low (Flanigan and Long, 1987) and relatively high-temperature ground water (Iovenitti, 1990) occur in an area south of the lower east-rift zone of Kilauea ("geothermal" ground water in Fig. 2), and may be caused by lateral migration of a thermal plume from an upwelling zone near HGP-A (Ioventtti, 1990). However, the thermal imagery shows that, as of 1963, springdischarge temperatures in this particular area were lower than ocean temperatures, although the area was bounded by two discrete areas of relatively warm discharge. 
Historically documented springs are relatively uncommon between Cape Kumukahi and Hilo, but the thermal infrared imagery indicates that there is also substantial ground-water discharge along the east coast (Fig 2).

Hirashima, G.T., 1967, A determination of the daliy mean discharge of Walakea Pond springs in Geological Survey Research 1977, Chapter D: U.S. Geological Survey Professional Paper 575-D, p. D242-D246.

The largest measured discharge from sea-level springs on the Island of Hawail occurs in Hilo near Waiakea Pond. The total discharge of $-5,000 \mathrm{~L} / \mathrm{s}$ amounts to -38 of the recharge on Kilauea and adjacent parts of Mauna Loa (150,000 L/s: Takasaki, 1993).

Martin, W.F., and Plerce, C.H., 1913, Water resources of Hawai1 1909-1911: U.S. Geological Survey Water-Supply Paper 318, 552 p.

Pierce, C.H., and Larrison, G.K., 1914, Water resources of Hawail 1912: U.S. Geological Survey Water-Supply Paper 336, 392 p.

In 1910 the USGS entered into a cooperative agreement with the Governor of the Territory of Hawaii for "...the gaging of streams and the determination of the water supply...". These reports include some pre-1910 data.

U.S. Geological Survey, 1992, Water resources data Hawail and other Pacific areas, water year 1991. Volume 1. Hawa1i: U.S. Geological Survey Water-Data Report HI-91-1, 282 p.

Since 1961 USGS streamflow, ground-water level, and water-quality records for Hawaii have been published in annual reports entitled 'Water resources data Hawaii and other Pacific areas...' Records for the 1911-1960 period were published in annual Water-Supply Papers such as that of Pierce and Larrison (1914). There are currently 5 streamflow-gaging stations and 9 observation wells in the area bounded by the rift zones of Mauna Loa and the Pacific Ocean (Fig. 2). At some of these sites water-quality data are obtained on a regular basis.

Regrettably, during a recent review of streamflow data from the Island of Hawaii it was determined that many basic data had been fabricated by an individual no longer with the USGS. Streamflow data published during the last 25 years contain errors of unknown magnitude and extent.

See also Davis and Yamanaga (1968) for a suminary of streamflow records ( $p$. 16-23), Hawaii Department of Land and Natural Resources (1970) for data on streamflow ( $p .123-137$ ), springs ( $p .174-180$ ) and water quality ( $p .181$ 188), and Stearns and MacDonald (1946) for inventories of sea-level ( $p$. $253 f, 261 f$ ) and perched springs (p. 290f). 


\section{RAINFALL AND EVAPOTRANSPIRATION}

Both rainfall and evapotranspiration are highly variable on the Island of Hawaii. For example, in the area bounded by the rift zones of Mauna Loa and the Pacific Ocean mean annual rainfall ranges from 0.5 to $5 \mathrm{~m} / \mathrm{yr}$ (Fig. 3 ; Giambelluca and others, 1986). Rainfall seasonality is more pronounced in dry areas than in wet areas. In general, there is an inverse correlation between rainfall and pan evaporation (fig. 3), due to lowe: insolation rates and higher humidity in areas of high rainfall.

Ekern, P.C., and Chang, J.-H., 1985, Pan evaporation: State of Hawail, 1894-1983: Hawa1i Division of Water and Land Development, Dept. of Land and Natural Resources Report R74, 171 p.

Includes pan-evaporation data ( $p, 43-47$ ) and a map of adjusted pan evaporation ( $p$. 46) for the Island of Hawail; also a general discussion of the use of pan evaporation records ( $p .48-50$ ).

Glambelluca, T.W., 1986, Land-use effects on the water balance of a tropical island: National Geographic Research, v. 2, p. 125-151.

Giambelluca, T.W., and Nullet, Dennis, 1992, Evaporation at high elevations in Hawa11: Journal of Hydrology, v. 136, p. 219-235.

The 1986 paper describes Thornthwaite-type water-balance calculations for a study area that includes much of leeward Oahu. Mean annual and monthly rainfall, irrigation, runoff, evapotranspiration, and ground-water recharge were obtained for many spatial units. Giambelluca calculated that in natural areas with $2-2.5 \mathrm{~m} / \mathrm{yr}$ rainfall about $50 \mathrm{z}$ of incident rainfall recharges the ground-water system ( $p .40$ ). This agrees with Takasak1's (1993) estimate that 50.608 of the rainfall on Kilauea and adjacent parts of Mauna Loa recharges the ground-water system. Giambelluca's model was driven by climate records from 1946-1975.

The 1992 paper showed that evaporation on Haleakala, Island of Maui, increased with elevation, reaching $2.3 \mathrm{~m} / \mathrm{yr}$ at $2130 \mathrm{~m}$. The rate increase is related to the presence of very dry and relatively warm air above the inversion layer.

Giambelluca, T.W., Nullet, M.A., and Schroeder, T.A., 1986, Rainfall atlas of Hawail: Hawaii Division of Water and Land Development, Dept. of Land and Natural Resources Report R76, 267 p.

Includes maps of annual ( $p .34$ ) and monthly ( $p .35-46$ ) median rainfall, annual (p. 99) and monthly ( $p .100-111$ ) mean rainfall, and extensive tables of data ( $p .164-191$ ) for the Island of Hawail. 
National Oceanic and Atmospheric Administration, 1992, Hawail and Paciffc 1991: Climatological data annual summary, $v .87$, no, $13,35 \mathrm{p}$.

NOAA publishes monthly and annual-summary climate data, including extensive precipitation and air-temperature data and sparser soil-temperature, evaporation, and wind-movement data. The current NOAA reporting network includes about 20 precipitation stations in the area bounded by the rift zones of Mauna Loa and the Pacific Ocean.

See also Hawail Department of Land and Natural Resources (1970) for both rainfall (p. 12-78) and evaporation ( $p .103-109$ ) data, Davis and Yamanaga (1968) for a summary of rainfall at selected stations in the Hilo-Puna area (p. 9-15), and Martin and Pierce (1913, p. 462-486), Pierce and Larrison (1914, p. 385), Stearns and Clark (1930, p. 167-173), and Stearns and MacDonald (1946, p. 211-217) for earlier rainfall data. Takasaki (1993) combined rainfall data with estimates of evapotranspiration to map estimated ground-water recharge.

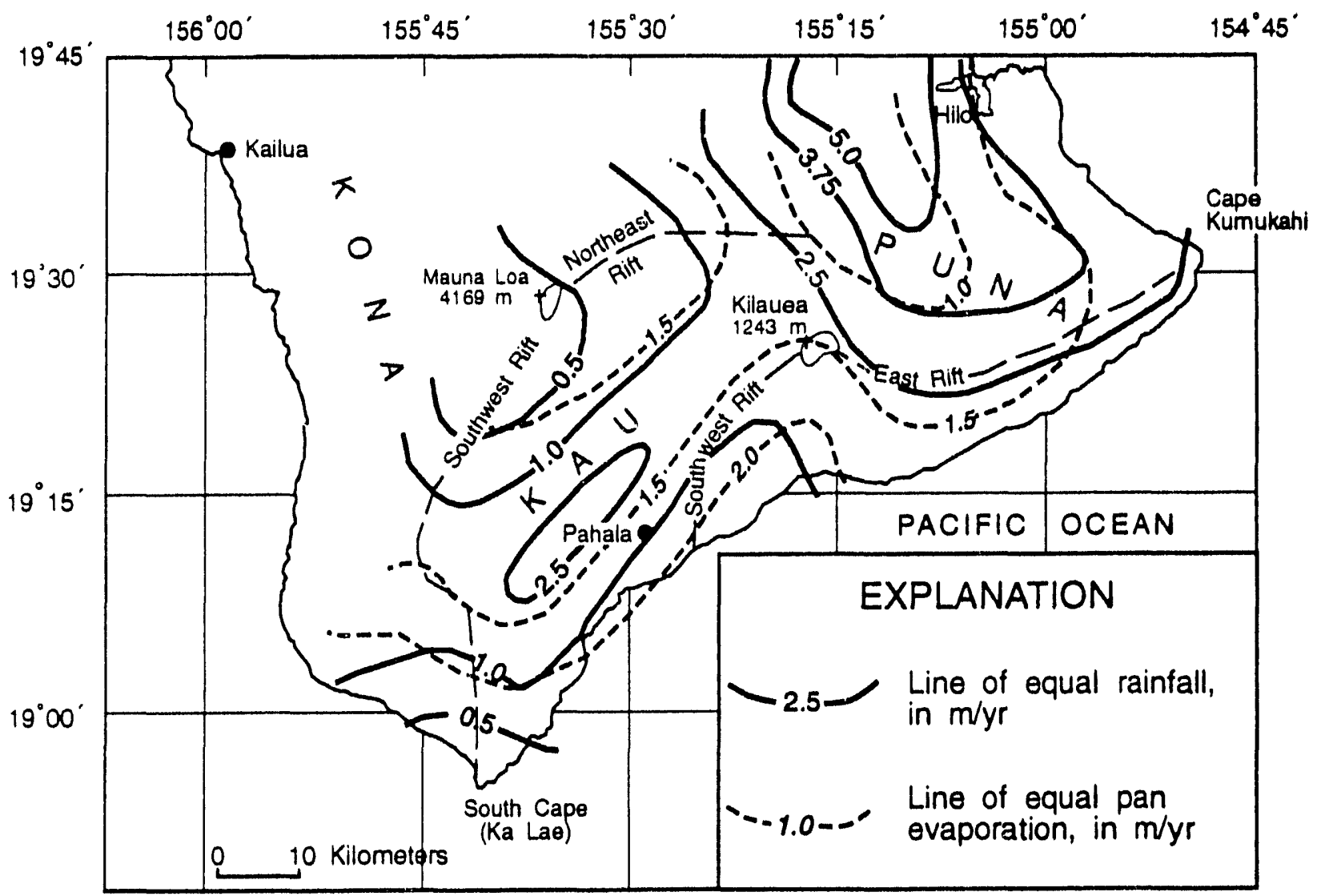

Fig. 3 Average annual rainfall and pan evaporation, Kau and Puna districts, Island of Hawail. Rainfall contours from USGS (1986), pan evaporation from Ekern and Chang (1985). 
Most basal ground waters that have been sampled are brackish sodium-chloride waters, though some wells tapping the upper part of the fresh-water lens produce sodium-bicarbonate waters (Swain, 1973). Perched or dike-impounded ground waters are typically low-salinity sodium-bicarbonate waters.

Goff, Fraser, McMurtry, G.M., and Adams, A.I., 1991, Deuterium, tritium, and oxygen-18 in meteoric, geothermal, and magmatic waters at Kilauea Volcano, Hawaii (abs.): Eos, Transactions American Geophysical Union, v. 72, Fall Meeting Supplement, p. 558.

Describes deuterium and oxygen-18 values for cold meteoric waters and sea water ranging from 0 to $-102 \% / 00 \partial D$ and 0 to $-13.5 \% / 00 \partial^{18} 0$, respectively, with areal variation controlled primarily by elevation differences; also tritium contents of shallow cold waters averaging $2.4 \pm 0.3$ T.U. $(n=13)$. Tritium in shallow geothermal waters of Kilauea's lower east-rift zone ranges from 2.6 to $4.4 \mathrm{~T} . \mathrm{U}$. and is inversely correlated with chloride; the authors explain this relation in terms of mixing between older meteoric water and seawater.

McMurtry, G.M., Fan, P.-F., and Coplen, T.B., 1977, Chemical and isotopic investigations of groundwater in potential geothermal areas in Hawaif: American Journal of Science, v. 277, p. 438-458.

Presents deuterium, oxygen-18, and silica-concentration data for ground water from 27 low-elevation wells. The rather sparse silica data from the Puna District were contoured (p. 451); highest measured concentrations occur in the lower east-rift zone and indicated equilibrium temperatures of 160 $275^{\circ} \mathrm{C}$. The silica-concentration map is generally similar to that of Druecker and Fan (1977).

Schol1, M.A., Ingebritsen, S.E., Jarik, C.J., and Kauahikaua, J.P., 1992, Geochemical and stable-isotope composition of precipitation and groundwater, Kilauea volcano area, Hawaii - preliminary results (abs.): October 27, 1992 Supplement to Eos, Transactions American Geophysical Union, p. 161.

Documents a rate of decrease in deuterium content of precipitation of 17 o/oo per $1,000 \mathrm{~m}$ elevation; 928 of the variance in the data was explained by elevation differences. Sulfate concentrations in the 72 precipitation samplers ranged from $<2$ to $70 \mathrm{mg} / \mathrm{L}$, with the highest concentrations occurring in sites downwind from Kilauea caldera. Chloride concentrations ranged from $<1$ to $16 \mathrm{mg} / \mathrm{L}$; the highest values were from sites near the coast. 
Swain, L. A., 1973, Chemical quality of ground water in Hawail: Hawaii Division of Water and Land Development, Dept. of Land and Natural Resources Report R48, 54 p.

A comprehensive summary of water-chemistry data that includes analyses from 56 wells on the Island of Hawaii (p. 53f), including 21 wells in the South Hilo, Puna, and Kau districts. Most basal ground waters that have been sampled are brackish sodium-chloride waters, although some wells tapping the upper part of the fresh-water lens produce sodium-bicarbonate waters ( $p$. 32). Swain ( $p .32$ ) suggested that basal ground water from two wells with relatively high bicarbonate concentrations had been affected by volcanic activity. Chemical data from these wells are shown below. One is at Kapoho crater (lower east-rift zone), the other penetrates lavas of Hualalai volcano near Kailua (Fig. 2).

\begin{tabular}{|c|c|c|c|c|c|c|c|c|}
\hline & & $\mathrm{pH}$ & $\mathrm{Ca}$ & $\mathrm{Mg}$ & $\mathrm{Na}$ & $\mathrm{K}$ & $\mathrm{HCO}_{3} \mathrm{SO}_{1}$ & $\mathrm{Cl}$ \\
\hline Kapoho crater & $3 / 03 / 72$ & 8.4 & 72 & 31 & 57 & 7.6 & $393{ }^{3}$ & $\overline{54}$ \\
\hline Hualalai volcanics & $3 / 1 i / 72$ & 8.0 & 28 & $\begin{array}{l}69 \\
\text { (c }\end{array}$ & $\begin{array}{l}270 \\
\text { cent }\end{array}$ & $\begin{array}{l}13 \\
\text { ation }\end{array}$ & $\begin{array}{l}42475 \\
\text { in } \mathrm{mg} / \mathrm{L} \text { ) }\end{array}$ & 370 \\
\hline
\end{tabular}

On the basis of Ghyben-Herzbelg assumptions, Swain ( $p .32$ ) concluded that the fresh-water lens beneath the Is land of Hawaii cannot be thick. This conclusion has since been disproved by drill-hole data.

Tilling, R.I., and Jones, B.F., 1991, Composition of waters from the research drill hole at summit of Kilauea Volcano and of selected thermal and nonthermal groundwaters, Hawafi: U.S. Geological Survey Open-File Report 91-133-A, 27 p.

Includes a time series of water-chemistry data from the 1,262-m-deep NSFfunded research drill hole above Kilauea's magma reservoir. The relatively saline, bicarbonate- and sulfate-rich waters that underlie Kilauea's summit and (perhaps) upper rift zones are atypical; their composition is presumably related to the ongoing volcanic activity. Low-salinity sodium-bicarbonate waters sampled near Pahala (Fig. 2; Swain, 1973, well 1128-01) provide a more representative example of perched or dike-impounded waters (see below). The composition of ground water below Kilauea summit was observed to change following the major eruptive and intrusive activity in the upper southwestrift zone in December 1974: bicarbonate concentrations increased by a factor of five, and sulfate and chloride concentrations declined (see below).

Pahala

NSF drill hole on Kilauea summit
$4 / 13 / 72$

$\frac{\mathrm{pH}}{7.2}$

$$
12 / 18 / 74
$$

$8.2 \quad 49$
$6 / 06 / 75$

$7.6 \quad 72$

$\mathrm{Ca}$

$\frac{\mathrm{Mg}}{3.6}$

$\mathrm{Na}$
6

$64 \quad 769$

$87 \quad 730 \quad 111$

$730-111$ 
Table 3 presents chemical analyses from the NSF drill hole, and Table 4 consists of analyses from wells in Volcano village, local rain, and streams and high-elevation permafrost cracks on Mauna Loa. The water-chemistry data of McMurtry and others (1977) are summarized in Tables 9 and 10, and those of Swain (1973) in Table 11.

See also Stearns and MacDonald (1946) for additional chemical analyses of spring, tunnel, wel1, stream, and ocean water (p. 289), Hawaii Department of Land and Natural Resources (1970) for time-series data from selected sites (p. 181-187), Druecker and Fan (1976) for temperature and chloride data for selected coastal water holes, wells, ponds, and springs ( $p .334$ ) and maps of chloride ( $p .335$ ) and silica ( $p .337$ ) concentrations in Puna, and the annual USGS Water Resources Data volume for time-series data on specific

conductance and chloride concentrations in selected wells (e.g., p. 260-263 and p. 275-276 in the Water Year 1991 volume contain data from the south part of the Island of Hawaii). Numerous other references discuss the chemical composition of geothermally heated ground water in the lower east. rift zone of Kilauea; some are described in this report under 'Hydrothermal systems/hydrothermal modeling' (e.g., ENEL, 1990; GeothermEx, 1992; Thomas, 1982, 1987). 


\section{PERMEABILITY}

Various numerical-modeling results and sparse field observations permit some general inferences about the permeability structure of Kilauea volcano. Permeability measurements are highly scale-dependent, and most values obtained from Hawailan well tests and model results apply to scales ranging from perhaps $100 \mathrm{~m}$ to tens of $\mathrm{km}$. Over such scales, the permeability of Kilauea rocks probably ranges from $>10^{-10} \mathrm{~m}^{2}$ to $<10^{-15} \mathrm{~m}^{2}$, depending on the morphology of the lava flows, the frequency of dike intrusion, and the degree of hydrothermal alteration. Permeability at depth in the rift zones $\left(\leq 10^{-15} \mathrm{~m}^{2}\right)$ is much lower than that of unaltered basalt flows closer to the surface $\left(\geq 10^{-10} \mathrm{~m}^{2}\right)$. It is not clear whether pervasive intrusion or alteration is the primary cause of the relatively low bulk permeability at depth in the east-rift zone. Both are probably important, and related by the role of recently emplaced dikes as heat sources that help drive alteration.

Chen, B.H., Kihara, D.H., Yuen, P.C., and Takahashi, P.K., 1978, We11-test results from HGP-A: Geothermal Resources Council Transactions, v. 2, p. $99-104$.

Chen, B.H., Kihara, D.H., Seki, A., and Yuen, P.C., 1979, Well-test analysis of HGP-A: Society of Petroleum Engineers of AIME Paper SPE 7963, presented at the 1979 California Regional Meeting, Ventura, April 18 20, unpaginated.

On the basis of permeability-thickness (transmissivity) estimates in the range of $880-1,553$ millidarcy-feet, the average permeability of the deep (500-1,800 $\mathrm{m}$ below sea level) uncased interval in this lower-east-rift zone well is $2-4 \times 10^{-16} \mathrm{~m}^{2}$. Chlorite and montmorillinite, which occur interstitially and fill vesicles and fractures, are the dominant alteration minerals in this interval (Stone, Claudia, and Fan, P.-F., 1978, Hydrothermal alteration of basalts from Hawaii Geothermal Project well-A, Kilauea, Hawaii: Geology, v. 6, p. 401-404).

Eyre, P.R., 1985, Simulation of ground-water flow in southeastern Oahu, Hawa11: Ground Water, v. 23, p. 325-330.

This study ( $p .327$ ) assigned a permeability value of $2 \times 10^{-10} \mathrm{~m}^{2}$ to the Koolau aquifer of southern Oahu.

Hardee, H.C., 1980, Solidification in Kilauea Iki lava lake: Journal of Volcanology and Geothermal Research, v. 7, p. 211-223.

In this study the permeability of the crust of Kilauea Iki lava lake was determined to be $-3 \times 10^{-13} \mathrm{~m}^{2}$. The in situ measurements sampled comparatively small volumes of rock. 
Imada, J.A., 1984, Numerical modeling of the groundwater in the east rift zone of Kilauea Volcano, Hawail: M.S. thesis, University of Hawail, Honolulu, $102 \mathrm{p}$.

Imada simulated fluid flow and solute transport in a $20 \mathrm{~km}$ (NE-SW) by $12 \mathrm{~km}$ (NW-SE) area extending westward from Cape Kumukahi (Fig. 2). Her best match of observed water-table elevations was obtained by assigning permeability values of $5 \times 10^{-9} \mathrm{~m}^{2}$ to rocks outside of Kilauea's east-rift zone; $1 \times 10^{-9}$ $\mathrm{m}^{2}$ to rift-zone rocks within $10 \mathrm{~km}$ of Cape Kumukahi; and $1 \times 10^{-11} \mathrm{~m}^{2}$ to rift-zone rocks more than $10 \mathrm{~km}$ from the cape. The higher permeability of the eastern part of the rift zone was attributed to decreasing dike density (p. 71).

Murray, J.C., 1974, The geothermal system at Kilauea Volcano, Hawal: Ph.D. thesis, Colorado School of Mines, Golden, 86 p.

Murray ( $p$. 58-60) estimated the permeability of the 500- to 1,200-m-depth interval in the NSF drillhole on Kilauea summit to be $1 \times 10^{-14} \mathrm{~m}^{2}$ on the basis of rates of mud loss during drilling. He inferred (p. 61) a value of $6 \times 10^{-14} \mathrm{~m}^{2}$ from numerical modeling experiments that attempted to match the distinctive temperature profile. Both values are significantly larger than the permeability of core samples obtained in that interval ( $p .56-57 ;-5 \times$ $\left.10^{-17} \mathrm{~m}^{2}\right)$. Discrepancies of such magnitude $\left(-10^{3}\right)$ between core measurements and in situ or inferred values are commonly observed in fractured crystalline rocks (Brace, W.F., 1980, Permeability of crystalline and argillaceous rocks: Int1. Journal of Rock Mechanics and Mining Sclences and Geomechanics Abstracts, v. 17, p. 241-251).

Olson, H.J., and Deymonaz, J.E., 1992, The the Hawailan scientific observation hole ( $\mathrm{SOH}$ ) program summary of activities: Geothermal Resources Council Transactions, v. 16, p. 47-53.

Includes (their Fig. 3) temperature profiles from three deep wells ("Scientific Observation Holes") in the lower east-rift zone of Kilauea. The profiles appeur quasi-conductive at depths greater than $-1 \mathrm{~km}$ below sea level. Below that depth gradients range from 170 to $330^{\circ} \mathrm{C} / \mathrm{km}$, and measured temperatures range from 100 to $350^{\circ} \mathrm{C}$. Ingebritsen and Scholl (1993) indicated that the apparent absence of large-scale convective circulation despite such high gradients implies bulk permeabilities $<10^{-14} \mathrm{~m}^{2}$.

Souza, W.R., and Voss, C.I., 1987, Analysis of an anisotropic coastal aquifer system using variable-density flow and transport simulation: Journal of Hydrology, v. 92, p. 17-41.

Voss, C.I., and Souza, W.R., 1987, Variable density flow and solute transport simulation of regional aquifers containing a narrow freshwater-saltwater transition zone: Water Resources Research, v. 23, p. $1,851-1,86 \epsilon$.

Voss and Souza ( $p .1,861$ ) assigned a value of $5 \times 10^{-10} \mathrm{~m}^{2}$ to the southern Oahu aquifer system. Though limited well-test data suggest that vertical 
permeability is perhaps 10 to 100 times less than horizontal permeability (P.A. Hsieh, U.S. Geological Survey, oral commun., 1991), modeling studies, which estimate larger-scale permeabilities, have tended to invoke somewhat larger degrees of anisotropy (e.g., Souza and Voss, p. 31).

Williams, J.A., and Soroos, R.I., 1973, Evaluation of methods of pumping test analysis for application to Hawalian aquifers: Water Resources Research Center Technical Report 20, University of Hawaii, Honolulu, $159 \mathrm{p}$.

The average of 21 aquifer-test measurements of Hawaiian basalts reported by the authors is $1.8( \pm 1.4) \times 10^{-10} \mathrm{~m}^{2}$.

See also Takasaki (1993) for water-budget-based permeability estimates that range from $10^{-11} \mathrm{in}^{2}$ for the upper east-rift zone to $>10^{-9} \mathrm{~m}^{2}$ for the lower east-rift zone and Davis and Yamanaga (1973) for specific-capacity data from 10 wells on the Island of Hawail. 
HYDROTHERMAL SYSTEMS/HYDROTHERMAL MODELING

The papers described in this section are a sample of the voluminous literature on Kilauez's hydrothermal system and hydrothermal modeling. We chose to emphasize conceptual models of the Kilauea system and related quantitative modeling. Like most quantitative modeling studies of fluid flow near intrusions, those of Kilauea have generally assumed that the circulating fluid is pure water. The kilauea studies also involved idealized, two-dimensional geometries and invoked certain simplifying assumptions. Most important, fluid properties were assumed to be constant, except for fluid density in the bouyancy force term (the Boussinesq approximation), and the temperature of the fluid was assumed to be below the boiling-point temperature for the ambient pressure. Some current computersimulation codes avoid these approximations, at least for the case of subcritical $\left(\leq 350^{\circ} \mathrm{C}\right.$ ) pure-water systems, and some models can simulate fluid flow with coupled heat and solute transport at relatively low temperatures. However, no existing code solves the coupled problem over the entire temperature $\left(0-1,200^{\circ} \mathrm{C}\right.$ ) and salinity range (perhaps $0-20$ percent $\mathrm{NaCl}$ : Fournier, 1987) of a Kilauea-like system (Fig. 4).

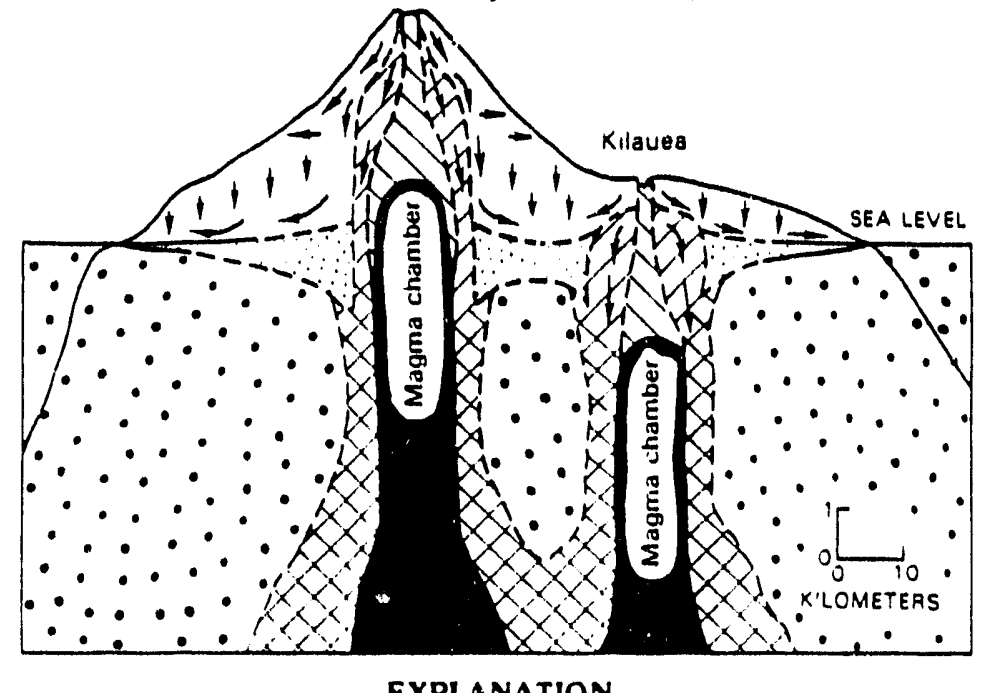

EXPLANATION

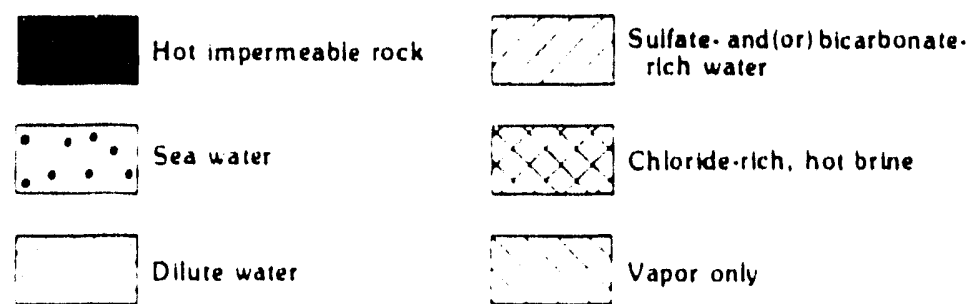

Fig. 4 Conceptual model of shallow magma reservoirs and associated hydrothermal systems beneath Mauna Loa and Kilauea volcanoes (from Fournier, 1987, Fig. 55.15). Arrows indicate inferred direction of water movement. 
Casadeva11, T.J., and Hazlett, R.W., 1983, Thermal areas on Kllauea and Mauna Loa volcanoes, Hawail: Journal of Volcanology and Geothermal Research, v. 16, p. $173-188$.

Inventories active thermal areas as of 1978-79. Thirty four of the 41 areas are located on Kilauea; most are areas of fume and steam discharge located along the rift zones and associated with recent eruptive fissures. Includes (p. 181) a table of temperature data from selected wells and springs.

Cheng, Ping, and Lau, K.H., 1974, Steady state free convection in an unconfined geothermal reservoir: Journal of Geophysical Research, $v$. 79 , p. 4, 425-4,431.

Cheng, Ping, and Lau, K.H., 1978, Modelling of a volcanic island geothermal reservoir: Hawail Geothermal Project Report SAN-1093-T5, University of Hawa11, Honolulu, $39 \mathrm{p}$.

Cheng, Plng, and Teckchandani, Lall, 1977, Numerical solutions for transient heating and fluid withdrawal in a liquid-dominated geo hermal reservoir in Heacock, J.D., ed., The Earth's crust: its nature and physical properties: American Geophysical Union Monograph 20, p. 705-721.

Lau, K.H., and Cheng, Ping, 1977, The effect of dike intrusion on free convection in conduction-dominated geothermal reservolrs:

International Journal of Heat and Mass Transfer, v. 20, p. 1,205-1,210.

This set of papers describes very generalized models that were loosely based on the Kilauea system. Like Murray (1974), Cheng and Lau (1978, p. 10) showed that the distinctive temperature profile from the NSF drill hole at Kilauea summit can be explained in terms of free convection in a confined aquifer. Cheng and Lau (1974) simulated free convection in an unconfined geothermal reservoir and Lau and Cheng (1977) considered the thermal effects of dike intrusion into an unconfined reservoir. Both the 1974 and 1977 studies illustrate how the distribution of heat sources might affect the thermal field in a reservoir. Lau and Cheng ( $p, 1,209)$ suggested that the water table rises in response to dike emplacement. This result was due to thermal expansion of the fluid and should be considered semi-quantitative, because some factors that could influence water-table response were neglected: fluid viscosity was assumed constant, and the mechanical effects of diking were not treated.

ENEL (Ente Nazionale per l'Energia Elettrica), 1990, The Kilauea east rift zone: geothermal evaluation of the existing data: Draft report prepared for the State of Hawail, Department of Business, Economic Development, and Tourism, $103 \mathrm{p}$.

This report was contracted by the State of Hawai, and summarizes publicly available geophysical, water-chemistry, drilling, and well-test data. The well data are from wells drilled in the east-rift zone prior to 1986. 
Forster, Craig, and Smith, Leslie, 1988, Groundwater flow systems in mountainous terrain 2. Controlling factors: Water Resources Research, v. 24, p. $1,011-1,023$.

Forster, Craig, and Smith, Leslie, 1989, The influence of groundwater flow on thermal regimes in mountainous terrain: A model study: Journal of Geophysical Research, v. 94, p. 9,439-9,451.

Of the many generic quantitative-modeling studies, these are among the most relevant to the understanding of Kilauea, because they deal with flow and heat transport in an unconfined, mountainous flow system. The authors illustrated some of the factors controlling water-table configurations and temperature fields.

Fournier, R.O., 1987, Conceptual models of brine evolution in magmatichydrothermal systems in Decker, R.W., Wright, T.L., and Stauffer, P.H., eds., Volcanism in Hawa11: U.S. Geological Survey Professional Paper 1350, p. $1,487-1,506$.

Presents a conceptual model of shallow magma reservoirs and associated hydrothermal systems beneath Mauna Loa and Kilauea volcanoes. Includes ideas about the evolution of the hydrothermal system during growth of the volcano. The schematic diagram included as Figure 4 of this report is Fig. 55.15 (p. 1,500) of Fournier (1987).

GeothermEx, Inc., 1992, Annual report: geothermal resource assessment: Report prepared for the State of Hawai1, Department of Business, Economic Development, and Tourism, $240 \mathrm{p}$.

This report was contracted by the State of Hawaii, and includes analysis of drilling and well-test results, a conceptual model for the lower east-rift zone, and resource estimates. Nine wells have "proven" the Puna geothermal reservoir. Thermai fluid is channeled along steeply dipping structures that parallel the east-rift zone. Large horizontal pressure and temperature gradients indicate low horizontal permeability normal to the rift zone. The high-permeability structures are probably related to fracturing during dike emplacement. Reserves of geothermal energy are estimated to amount to 140 . $160 \mathrm{MW}$.

This report contains more data from deep geothermal wells than the earlier report by ENEL (1990). 
Iovenitt1, J.L., 1990, Shallow ground water mapping in the lower east rift zone, Kllauea Volcano: Geothermal Resources Council Transactions, $v$. 14, part 1, p. 699-703.

Ioventtti, J.L., and D'Olier, W.L., 1985, Preliminary results of drilling and testing in the Puna geothermal system, Hawa11: Proceedings of the Tenth Workshop on Geothermal Reservoir Engineering, Stanford UnIversity, p. 65-71.

Data from deep geothermal wells have facilitated relatively detalled hydrologic and geochemical models of Kllauea's lower east-rift zone, including those of lovennitt and colleagues. The 1985 paper is based largely on results from the Kapoho State-1 and -2 wells and includes (their Fig. 2) a pressure/temperature profile for $\mathrm{KS}-2(2,440 \mathrm{~m} \mathrm{depth})$ and temperature profiles from KS-1 $(2,223 \mathrm{~m}$ depth) and the earlier HGP-A well $(1,966 \mathrm{~m}$ depth $)$. The hydrothermal system in the lower east-rift zone was described as a "blind" two-phase liquid-dominated system masked by overlying ground water and effectively sealed by impermeable rocks (their Fig, 5). The 1990 paper described a geothermal plume extending from the vicinity of HGP-A and the KS wells to the coastline (FIg. 2). The plume was defined on the basis of elevated temperatures in two wells and generally coincides with an apparent resistivity low mapped by Flanigan and Long (1987). It is attributed to upwelling of geothermal fluids at a transverse structural break in the lower east-rift zone, followed by lateral flow along the topographic gradient. The thermal infrared imagery of Fischer and others (1966) shows that, as of 1963, basal ground-water discharge temperatures in this particular area were generally lower than ocean temperatures, although the area was bounded by two discrete areas of relatively warm discharge (Fig. 2).

Keller, G.V., Grose, L.T., Murray, J.C., and Skokan, C.K., 1979, Results of an experimental drill hole at the summit of Kllauea Volcano, Hawa11: Journal of Volcanology and Geothermal Research, v. 5, p. 345-385.

Describes results from the 1,262-m-deep NSF-funded drill hole on Kilauea sumit. Data from this drill hole ( $p .355$ ) established that the water table beneath Kilauea summit is about 610 meters above sea level. Reduced permeability $\left(10^{-14}\right.$ to $\left.10^{-13} \mathrm{~m}^{2}\right)$ below about $500 \mathrm{~m}$ depth is assoclated with partial filling of vesicles by secondary mineralization ( $p .353$ ) and temperatures $>60{ }^{\circ} \mathrm{C}$ (their Fig. 14).

See descriptions of the work by Tilling and Jones (1991) under 'Water quality', that of Murray (1974) under 'Permeability', and that of Jackson and Kauahikaua (1987, 1990) under 'Geophysics/other' for further discussion of results from this drill hole. 
Kroopnick, P.M., Buddemeler, R.W., Thomas, Donald, Lau, L.S., and B1lls, D., 1978, Hydrology and geochemistry of a Hawallan geothermal system: HGPA: Hawal1 Institute of Geophysics Technical Report HIG 78-6, $64 \mathrm{p}$.

Describes production of low-salinity waters by the HGP-A well from depths as great as $1,700 \mathrm{~m}$ below sea level ( $p .14-19$ ); also reports 1977 tritium values of less than 0.2 T.U., indicating the absence of bomb-produced tritium ( $p, 51)$. The Ghyben-Herzberg model would predict only a $70-m$-thick fresh-water lens in the vicinity (Thomas, 1987, p. 1,519). The land-surface elevation is $194 \mathrm{~m}$ above sea level at HGP-A, and the water-table elevation in the vicinity is less than $2 \mathrm{~m}$ (Takasaki, 1993).

Lister, C.R.B., 1983, The basic physics of water penetration into hot rock in Rona, P.A., Bostrom, Kurt, Laubler, Lucien, and Smith, K.I., Jr. (eds.), Hydrothermal processes at seafloor spreading centers: New York, Plenum Press, p. 141-168.

Norton, Denis, and Taylor, H.P., Jr., 1979, Quantitative simulation of the hydrothermal systems of crystallizing magmas on the basis of transport theory and oxygen 1sotope data: an analysis of the Skrergaard intrusion: Journal of Petrology, v. 20, p. 426-486.

Works that provide general insight into high-temperature ground-water flow near intrusions. (The work of Forster and Smith (1988, 1989) focused on relatively low-temperature systeins.)

Pruess, Karsten, 1991, TOUGH2 - A general-purpose numerical simulator for multiphase fluid and heat flow: Lawrence Berkeley Laboratory Rept. LBL-29400, 102 p.

Documentation for a hydrothermal simulation model that is currently considered state-of-the-art. TOUGH2 combines solutions to fluid-flow, heatand (partial) solute-transport equations. However, even TOUGH2 is 1 imited to subcritical temperatures, and the solute-transport algorithm is not yet documented. No existing code solves the coupled problem over the entire temperature $\left(0-1,200^{\circ} \mathrm{C}\right.$ ) and salinity range (perhaps $0-20$ percent $\mathrm{NaCl}$ : Fournier, 1987) of a Kilauea-like system (Fig. 4).

Thomas, D.M., 1982, A summary of the chemlcal characteristics of the HGP-A we11; Puna, Hawa11: Proceedings of the E1ghth Workshop on Geothermal Reservoir Engineering, Stanford University, p. 309-313.

Thomas, D.M., 1987, A geochemical model of the Kilauea east-rift zone in Decker, R.W., Wright, T.L., and Stauffer, P.H., eds, Volcanism in Hawa11: U.S. Geological Survey Professional Paper 1350, p. 1,5071,525 .

Like Iovenitti and colleagues. Thomas has workec to develop more detalled models of hydrothermal circulation in the lower east-rift zone. He has published about a dozen papers and abstracts on the topic; the 1987 paper is probably the most comprehensive. 
The 1982 paper describes changes in the chemistry of fluids produced from HGP-A between 1976-1982 (Table 2); chloride concentrations increased from about $2,200 \mathrm{mg} / \mathrm{L}$ to $6,000 \mathrm{mg} / \mathrm{L}$. The data were interpreted in terms of fluid production from at least two separate aquifers. The aquifer fluids were belleved to consist largely of fresh meteoric water, and the increase in salinity was attributed to an increasing contribution of hydrothermally altered sea water.

The 1987 paper presents a more complete model of the east-rift zone. Selfsealing by hydrothernal alteration may help isolate relatively low-salinity hydrothermal systems in Kilauea's lower east-rift zone from salt-water intrusion; anhydrite deposition by heated sea water is a potentially linportant process ( $p, 1,520)$. This mechanism has been documented in the Reykjanes high-temperature area of Iceland's axial rift zone (Tomasson, Jens, and Smarason, O.B., 1985, Developments in geothermal energy: Hydrogeology in the service of man, Memolres of the $18 \mathrm{th}$ Congress of the International Association of Hydrogeologists, Cambridge, England, p. 189211). There, calcite and anhydrite deposition sustains pressure differences on the order of 10 bars across the boundaries of hydrothermal systems (Tomasson and Smarason, 1985, p. 197). The 1987 paper also includes a crude estimate of advective heat discharge by ground water for the subaerial part of the rift zone $(p, 1,512)$. The value of $1,455 \mathrm{MW}$ is compared to previously published estimates of the heat supplied by magmatic intrusion. 


\section{GEOPHYSICS/OTHER}

Flanigan, V.J., and Long, C.L., 1987, Aeromagnetic and near-surface electrical expressions of the Kllauea and Mauna Loa volcanic rift systems in Decker, R.W., Wright, T.L., and Stauffer, P.H., eds., Volcanism in Hawa11: U.S. Geological Survey Professional Paper 1350, p. $935-946$.

Flanigan, V.J., Long, C.L., Rohret, Donald, and Mohr, Pamela, 1986, Apparent-resistivity map of the rift systems of Kilauea and Mauna Loa volcanoes, Island of Hawa11, Hawa11: U.S. Geological Survey Miscellaneous Field Studies Map MF-1845-B, map scale 1:100,000.

In the 1987 report, selected resistivity lows transverse to the Kilauea's east-rift zone were tentatively.correlated with zones of thermal-fluid circulation ( $p, 940$ ). These data were used by Iovenitt1 (1990) to support his interpretation of a thermal plume extending from the area near HGP-A to the coastline. The 1986 map shows data from a low-level ( $90 \mathrm{~m}$ mean terrain clearance) electromagnetic survey that was the basis for the 1987 report.

Hussong, D.M., and Cox, D.C., 1967, Estimation of ground-water configuration near Pahala, Hawali, using electrical resistivity techniques: University of Hawail Water Resources Research Center Technical Report $17,35 \mathrm{p}$.

In 1946 an inclined shaft encouncered the water table at $70 \mathrm{~m}$ elevation near Pahala (Fig. 2), where the basal water table would be expected to be only $-1.5-3 \mathrm{~m}$ above sea level. The authors used electrical resistivity soundings to demonstrate that the water level measured in the shaft correlated with a coherent low-resistivity layer (their Fig. 3) extending at least $1.2 \mathrm{~km}$ northeast of the well and $0.8 \mathrm{~km}$ south of the well. They (p. 5) suggested that dikes subparallel to the southwest-rift zone of Kilauea and (or) an unconformity act(s) to impound ground water in the Pahala area.

See Adams, W.M., Mathur, S.P., and Huber, R.D., 1970, Aeromagnetic, gravity, and electrical resistivity exploration between Pahala and Punaluu, Hawali: Hawa11 Institute of Geophysics Technical Report 28, 62 p. for further discussion of possible ground-water barriers in the Pahala area.

Jackson, D.B., and Kauahikaua, James, 1987, Regional self-potential anomalies at Kilauea Volcano in Decker, R.W., Wright, T.L., and Stauffer, P.H., eds., Volcanism in Hawail: U.S. Geological Survey Professional Paper 1350, p. 947-959.

Jackson, D.B., and Kauahikaua, James, 1990, The high-level water table beneath Kilauea Volcano, Hawa1'i (abs.): Eos Transactions of the American Geophysical Union, v. 71 , p. 1,676

The 1987 paper describes resistivity line soundings that indicated the presence of high-level dike-impounded ground water beneath Kilauea's midand upper-east-rift zones. The 1990 abstract describes electrical soundings 
that identified a continuous high-level low-resistivity layer extending from Kilauea summit down the east-and southwest-rift zones. In the Kilauea summit region, the top of the low-resistivity layer coincides with the water-table position identified by Keller and others (1979). The layer abruptly deepens or disappears outside the rift zones; this might be due to a depth contrast (a deeper water table), a salinity contrast, or both. The data described in the 1990 abstract were used to define the water table in parts of Takasaki's (1993) water-table map area.

The application of electrical-resistivity methods to determine depth to salt water in Hawaii was first described in Swartz, J.H., 1940, Resistivitystudies of some salt-water boundaries in the Hawalian Islands: Transactions American Geophysical Union, 18th Annual Meeting, p. 387-393.

Characteristics of varfous electrical methods and numerous case studies were reviewed in Kauahikaua, James, 1990, The location and mapping of hydrologic regimes and thermal waters in Hawal'1: The use of electrical geophysical techniques: Geothermal Resources Counc1l Transactions, v, 14, p. 1,4891,492 .

Kauahikaua, James, 1993, Geophysical characteristics of Kilauea volcano's hydrothermal systems: Geothermics, v. 22, in press.

This comprehensive descriptic of the geophysical framework uses gravity, magnetic, and seismic velocity data to define the subsurface extent of Kilauea's volcanic-rift structures: estimates water-table configuration on the basis of electrical-resistivity data; summarizes self-potential results that suggest localized, thermally driven fluid circulation; and estinates heat-flow values of $370-820 \mathrm{~mW} / \mathrm{m}^{2}$ for seven deep drill holes in the eastrift zone.

U.S. Geological Survey, 1986, Hawaii Volcanoes National Park and vicinity 1:100,000-scale topographic map, 19155-D3-PF-100.

A useful base map for regional-scale studies of Kilauea volcano; also reproduces the rainfall map incorporated in Figure 3 of this report. 


\section{REFERENCES}

Adams, W.M., Mathur, S.P., and Huber, R.D., 1970, Aeromagnetic, gravity, and electrical resistivity exploration between Pahala and Punaluu, Hawaii: Hawail Institute of Geophysics Technical Report 28, 62 p. Cited under 'Geophysics/other'.

Brace, W.F., 1980, Permeability of crystalline and arglllaceous rocks: Intl. Journal of Rock Mechanics and Mining Sciences and Geomechanics Abstracts, v. 17, p. 241-251). Cited under 'Permeability'.

Casadevall, T.J., and Hazlett, R.W., 1983, Thermal areas on Kilauea and Mauna Loa volcanoes, Hawail: Journal of Volcanology and Geothermal Research, v. 16, p. 173-188. Cited under 'Hydrothermal systems/hydrothermal modeling'.

Chai, D.K., Cuddihy, L.W., and Stone, C.P., 1989, An inventory and assessment of anchialine pools in Hawaii Volcanoes National Park from Waha'ula to Ka'aha, Puna and $\mathrm{Ka}^{\prime} \mathrm{u}$, Hawa''l: Cooperative National Park Resources Study Unit, Department of Botany, University of Hawai'i, Technical Report $69,37 \mathrm{p}$. Cited under 'Surface-water hydrology'.

Chen, B.H., Kihara, D.H., Yuen, P.C., and Takahashi, P.K., 1978, Wel1-test results from HGP-A: Geothermal Resources Counc1l Transactions, v. 2, p. $99-104$. Cited under 'Permeability'.

Chen, B.H., Kihara, D.H., Seki, A., and Yuen, P.C., 1979, Well-test analysis of HGP-A: Society of Petroleum Engineers of AIME Paper SPE 7963, presented at the 1979 California Regional Meeting, Ventura, April 18 20, unpaginated.

Cited under 'Permeability'

Cheng, Ping, and Lau, K.H., 1974, Steady state free convection in an unconfined geothermal reservoir: Journal of Geophysical Research, v. 79 , p. $4,425-4,431$.

Cited under 'Hydrothermal systems/hydrothermal modeling'.

Cheng, Ping, and Lau, K.H., 1978, Modelling of a volcanic island geothermal reservoir: Hawaii Geothermal Project Report SAN-1093-T5, University of Hawail, Honolulu, 39 p.

Cited under 'Hydrothermal systems/hydrothermal modeling'.

Cheng, Ping, and Teckchandani, Lall, 1977, Numerical solutions for transient heating and fluid withdrawal in a liquid-dominated geothermal reservoir in Heacock, J.D., ed., The Earth's crust: its nature and physical properties: American Geophysical Union Monograph 20, p. 705-721. Cited under 'Hydrothermal systems/hydrothermal modeling'.

Davis, D.A., and Yamanaga, George, 1966, Preliminary report on the water resources of the Kau District, Hawaii: Hawaii Division of Water and Land Development, Dept. of Land and Natural Resources Circular C27, 25 p.

Cited under 'General hydrogeology'. 
Davis, D.A., and Yamanaga, George, 1968, Preliminary report on the water resources of the Hilo-Puna area, Hawail: Hawail Division of Water and Land Development, Dept. of Land and Natural Resources Circular C45, 38 p.

Cited under 'General hydrogeology', 'Surface-water hydrology', and . 'Rainfall and evapotranspiration'.'

Davis, D.A., and Yamanaga, George, 1973, Water resources summary Island of Hawail: Hawaii Division of Water and Land Development, Dept. of Land and Natural Resources Report R47, $42 \mathrm{p}$.

Cited under 'General hydrogeology' and 'Permeability'.

Druecker, Michael, and Fan, P.-F., 1976, Hydrology and chemistry of ground water in Puna, Hawa11: Ground Water, v. 14, p. 328-338.

Cited under 'General hydrogeology' and 'Water quality'.

Ekern, P.C., and Chang, J.-H., 1985, Pan evaporation: State of Hawail, 1894-1983: Hawali Division of Water and Land Development, Dept. of Land and Natural Resources Report R74, 171 p. Cited under 'Rainfall and evapotranspiration'.

ENEL (Ente Nazionale per l'Energia Elettrica), 1990, The Kilauea east rift zone: geothermal evaluation of the existing data: Draft report prepared for the State of Hawaii, Department of Business, Economic Development, and Tourism, $103 \mathrm{p}$.

Cited under 'Water quality' and 'Hydrothermal systems/hydrothermal modeling'.

Eyre, P.R., 1985, Simulation of ground-water flow in southeastern Oahu, Hawail: Ground Water, v. 23, P. 325-330.

Cited under 'Permeability'.

Fischer, W.A., Davis, D.A., and Sousa, T.M., 1966, Fresh-water springs of Hawail from infrared images: U.S. Geological Survey Hydrologic Investigations Atlas HA-218.

Cited under 'General hydrogeology, 'Surface-water hydrology', and 'Hydrothermal systems/hydrothermal modeling'.

Flanigan, V.J., and Long, C.L., 1987, Aeromagnetic and near-surface electrical expressions of the Kilauea and Mauna Loa volcanic rift systems in Decker, R.W., Wright, T.L., and Stauffer, P.H., eds., Volcanism in Hawaii: U.S. Geological Survey Professional Paper 1350, p. $935-946$.

Cited under'Surface-water hydrology' and 'Geophysics/other'.

Flanigan, V.J., Long, C.L., Rohret, Donald, and Mohr, Pamela, 1986, Apparent-resistivity map of the rift systems of Kilauea and Mauna soa volcanoes, Island of Hawaii, Hawail: U.S. Geological Survey Miscellaneous Field Studies Map MF-1845-B, map scale 1:100,000. Cited under 'Hydrothermal systems/hydrothermal modeling' and 'Geophysics/other'.

Forster, Craig, and Smith, Leslie, 1988, Groundwater flow systems in mountainous terrain 2. Controlling factors: Water Resources Research, v. 24, p. $1,011-1,023$.

Cited under 'Hydrothermal systems/hydrothermal modeling'. 
Forster, Craig, and Smith, Leslie, 1989, The influence of groundwater flow on thermal regimes in mountainous terrain: A model study: Journal of Geophysical Research, v. 94, p. 9,439-9,451.

Cited under 'Hydrothermal systems/hydrothermal modeling'.

Fournier, R. 0., 1987, Conçeptual models of brine evolution.in magmatichydrothermal systems in Decker, R.W., Wright, T.L., and Stauffer, P.H., eds., Volcanism in Hawail: U.S. Geological Survey Professional Paper 1350, p. 1,487-1,506.

Cited under 'Hydrothermal systeins/hydrothermal modeling'.

GeothermEx, Inc., 1992, Annual report: geothermal resource assessment: Report prepared for the State of Hawail, Department of Business, Economic Development, and Tourism, $240 \mathrm{p}$.

Cited under 'Water quality' and 'Hydrothermal systems/hydrothermal modeling'.

Giambelluca, T.W., 1986, Land-use effects on the water balance of a tropical 1sland: National Geographic Research, v. 2, p. 125-151.

Cited under 'General hydrogeology' and 'Rainfall and evapotranspiration'.

Glambelluca, T.W., and Nullet, Dennls, 1992, Evaporation at high elevations in Hawail: Journal of Hydrology, v. 136, p. 219-235.

Cited under 'Rainfall and evapotranspiration'.

Giambelluca, T.W., Nullet, M.A., and Schroeder, T.A., 1986, Rainfall atlas of Hawaii: Hawail Division of Water and Land Development, Dept. of Land and Natural Resources Report R76, 267 p.

Cited under 'Rainfall and evapotranspiration'.

Goff, Fraser, McMurtry, G.M., and Adams, A.I., 1991, Deuterium, tritium, and oxygen-18 in meteoric, geothermal, and magmatic waters at kilauea Volcano, Hawail (abs.): Eos, Transactions American Geophysical Union, v. 72, Fall Meeting Supplement, p. 558.

Cited under 'Water quality'.

Hardee, H.C., 1980, Solidification in Kilauea Ikf lava lake: Journal of Volcanology and Geothermal Research, v. 7, p. 211-223. Cited under 'Permeability'.

Hawaii Department of Land and Natural Resources, 1970, An inventory of basic water resources data, Island of Hawail: Division of Water and Land Development Report R34, $188 \mathrm{p}$.

Cited under 'General hydrogeology', 'Surface-water hydrology', 'Rainfall and evapotranspiration', and 'Water quality'.

Hirashima, G.T., 1967, A determination of the daily mean discharge of Waiakea Pond springs in Geological Survey Research 1977, Chapter D: U.S. Geological Survey Professional Paper 575-D, P. D242-D246. Cited under 'Surface-water hydrology'.

Hunt, C.D., Jr., Ewart, C.J., and Voss, C.I., 1988, Region 27, Hawailan Islands in Back, William, Rosenshein, J.S., and Seaber, P.R., eds., The Geology of North America, v. 0-2, Hydrogeology: Boulder, Geological Soclety of America, p. 255-262.

Cited under 'General hydrogeology'. 
Hussong, D.M., and Cox, D.C., 1967, Estimation of ground-water configuration near Pahala, Hawail, using electrical resistivity techniques:

University of Hawail Water Resources Research Center Technical Report $17,35 \mathrm{p}$.

- Cited under' 'Geophysics/uthè' .

Imada, J.A., 1984, Numerical modeling of the groundwater in the east rift zone of Kilauea Volcano, Hawail: M.S. thesis, University of Hawa11, Honolulu, 102 p.

Cited under 'Permeability'.

Ingebritsen, S.E., and Scholl, M.A., 1993, The hydrogeology of kilauea volcano: Geothermics, in press.

Cited under 'General hydrogeology'.

Iovenitti, J.L., 1990, Shallow ground water mapping in the lower east rift zone, Kilauea Volcano: Geothermal Resources Councll Transactions, $v$. 14, part 1, p. 699-703.

Cited under 'Surface-water hydrology' and 'Hydrothermal systems/hydrothermal modeling'.

Iovenitti, J.L., and D'Olier, W.L., 1985, Preliminary results of drilling and testing in the Puna geothermal system, Hawali: Proceedings of the Tenth Workshop on Geothermal Reservolr Engineering, Stanford University, p. 65-71.

Cited under 'Surface-water hydrology' and 'Hydrothermal systems/hydrothermal modeling'.

Jackson, D.B., and Kauahikaua, James, 1987, Regional self-potential anomalies at Kilauea Volcano in Decker, R.W., Wright, T.L., and Stauffer, P.H., eds., Volcanism in Hawa11: U.S. Geological Survey Professional Paper 1350, p. 947-959.

Cited under 'General hydrogeology', 'Hydrothermal systems/hydrothermal modeling' and 'Geophysics/other'.

Jackson, D.B., and Kauahikaua, James, 1990, The high-level water table beneath Kilauea Volcano, Hawal'i (abs.): Eos Transactions of the American Geophysical Union, v. 71, p. 1,676

Cited under 'Hydrothermal systems/hydrothermal modeling' and 'Geophysics/other'.

Kauahikaua, James, 1990, The location and mapping of hydrologic regimes and thermal waters in Hawa'1: The use of electrical geophysical techniques: Geothermal Resources Council Transactions, v, 14, p. $1,489-1,492$. Cited under 'Geophysics/other'.

Kauahikaua, James, 1993, Geophysical characteristics of Kilauea volcano's hydrothermal systems: Geothermics, v. 22, in press. Cited under 'Geophysics/other'.

Keller, G.V., Grose, L.T., Murray, J.C., and Skokan, C.K., 1979, Results of an experimental drill hole at the summit of Kilauea Volcano, Hawail: Journal of Volcanology and Geothermal Research, v. 5, p. 345-385. Cited under 'Hydrothermal systems/hydrothermal modeling' and 'Geophysics/other'. . 
Kroopnick, P.M., Buddemeler, R.W., Thomas, Dona1d, Lau, L.S., and B11ls, D., 1978, Hydrology and geochemistry of a Hawailan geothermal system: HGPA: Hawali Institute of Geophysics Technical Report HIG 78-6, 64 p. Cited under 'Hydrothermal systems/hydrothermal modsling'.

Lau, K.H., and Cheng, Ping, 1977, The effect of dike intrusion on free convection in conduction-dominated geothermal reservoirs:

International Journal of Heat and Mass Transfer, v. 20, p. 1,205-1,210. Cited under 'Hydrothermal systems/hydrothermal modeling'.

Lister, C.R.B., 1983, The basic physics of water penetration into hot rock in Rona, P.A., Bostrom, Kurt, Laubler, Lucien, and Smlth, K.L., Jr. (eds.), Hydrothermal processes at seafloor spreading centers: New York, Plenum Press, p. 141-168.

Cited under 'Hydrothermal systems/hydrothermal modeling'.

Martin, W.F., and Plerce, C.H., 1913, Water resources of Hawa11 1909-1911: U.S. Geological Survey Water-Supply Paper 318, 552 p. Cited under 'Surface-water hydrology' and 'Rainfall and evapotranspiration'.

McMurtry, G.M., Fan, P.-F., and Coplen, T.B., 1977, Chemical and 1sotopic investigations of groundwater in potential geothermal areas in Hawail: American Journal of Science, v. 277, p. 438-458. Cited under 'Water quality'.

Murray, J.C., 1974, The geothermal system at Kllauea Volcano, Hawail: Ph.D. thesis, Colorado School of Mines, Golden, $86 \mathrm{p}$. Cited under 'Permeability' and 'Hydrothermal systems/hydrothermal modeling'.

National Oceanic and Atmospheric Administration, 1992, Hawail and Pacific 1991: Climatological data annual summary, v. 87, no. 13, 35 p. Cited under 'Rainfall and evapotranspiration'.

Norton, Denis, and Taylor, H.P., Jr., 1979, Quantitative simulation of the hydrothermal systems of crystallizing magmas on the basis of transport theory and oxygen isotope data: an analysis of the skaergaard intrusion: Journal of Petrology, v. 20, p. 426-486.

Cited under 'Hydrothermal systems/hydrothermal modeling'.

0lson, H.J., and Deymonaz, J.E., 1992, The the Hawailan scientific observation hole ( $\mathrm{SOH}$ ) program summary of activities: Geothermal Resources Council Transactions, v, 16, p. 47-53. Cited under 'Permeability'.

Peterson, F.L., 1981, Geological and hydrological framework: A history of development in Fujimura, F.N., and Chang, W.B.C., eds., Groundwater in Hawail: A century of progress: University of Hawali at Manoa, p. 114 .

Cited under 'General hydrogeology'.

Plerce, C.H., and Larrison, G.K., 1914, Water resources of Hawaii 1912: U.S. Geological Survey Water-Supply Paper 336, 392 p. Cited under 'Surface-water hydrology' and 'Rainfalli and evapotranspiration'.

Pruess, Karsten, 1991, TOUGH2 - A general-purpose numerical simulator for multiphase fluid and heat flow: Lawrence Berkeley Laboratory Rept. LBL-29400, 102 p.

Cited under 'Hydrothermal systems/hydrothermal modeling'. 
Scholl, M.A., Ingebritsen, S.E., Janik, C.J., and Kauahikaua, J.P., 1992, Geochemical and stable-isotope composition of precipitation and groundwater, Kllauea volcano area, Hawall - preliminary results (abs.): October 27, 1992 Supplement to Eos, Transactions American Geophysical

Union, pi 161.

Cited under 'Water quality'.

Souza, W.R., and Voss, C.I., 1987, Analysis of an anisotropic coastal aquifer system using variable-density flow and transport simulation: Journal of Hydrology, v. 92, p. 17-41. Clted under 'Permeability'.

Stearns, H.T., and Clark, W.O., 1930, Geology and water resources of the Kau District, Hawa11: U.S. Geological Survey Water-Supply Paper 616, 194 p. Cited under 'General hydrogeology' and 'Rainfall and evapotranspiration'.

Stearns, H.T., and MacDonald, G.A., 1946, Geology and ground-water resources of the Island of Hawa11: Hawail Division of Hydrography Bulletin 9, $362 \mathrm{p}$.

Cited under 'General hydrogeology', 'Surface-water hydrology', 'Rainfall and evapotranspiration', and 'Water quality'.

Stone, Claudia, and Fan, P.-F., 1978, Hydrothermal alteration of basalts from Hawal1 Geothermal Project well-A, Kilauea, Hawail: Geology, v. 6, p. 401-404).

Cited under 'Permeability'.

Swain, L. A., 1973, Chemical quality of ground water in Hawail: Hawail Division of Water and Land Development, Dept. of Land and Natural Resources Report R48, $54 \mathrm{p}$.

Cited under 'Water quality'.

Swartz, J.H., 1940, Resistivity-studies of some salt-water boundaries in the Hawalian Islands: Transactions American Geophysical Union, 18 th Annual Meeting, p. 387-393.

Cited under 'Geophysics/other'.

Takasak1, K.J., 1993, Ground-water occurrence in Kilauea Volcano and adjacent parts of Mauna Loa Volcano: U.S. Geological Survey Open-File Report 93-82, in press.

Cited linder 'General hydrogeology', 'Surface-water hydrology, 'Rainfall and evapotranspiration', 'Permeability', 'Hydrothermal systems/hydrothermal modeling', and 'Geophysics/other'.

Takasaki, K.J., and Mink, J.K., 1985, Dike-impounded ground-water reservoirs, Island of Oahu: U.S. Geological Survey Water-Supply Paper $2217,77 \mathrm{p}$.

Cited under 'General hydrogeology'.

Thomas, D.M., 1982, A summary of the chemical characteristics of the HGP-A we11; Puna, Hawal1: Proceedings of the Elghth Workshop on Geothermal Reservolr Engineering, Stanford University, p. 309-313. Cited under 'Water quality' and 'Hydrothermal systems/hydrothermal modeling'. 
Thomas, D.M., 1987, A geochemical model of the Kllauea east-rift zone in Decker, R.W., Wright, T.L., and Stauffer, P.H., eds., Volcanism in Hawa11: U.S. Geological Survey Professlonal Paper 1350, p. 1,507$1,52,5$. Cited under' 'Watèr quality' and 'Hydrothermal systems'hydrothermal modeling' .

Tilling, R.I., and Jones, B.F., 1991, Composition of waters from the research drill hole at summit of Kilauea Volcano and of selected thermal and nonthermal groundwaters, Hawa11: U.S. Geological Survey Open-File Report 91-133-A, 27 p.

Cited under 'Water quality' and 'Hydrothermal systems/hydrothermal modeling.

Tomasson, Jens, and Smarason, O.B., 1985, Developments in geothermal enargy: Hydrogeology in the service of man, Memolres of the 18th Congress of the International Association of Hydrogeologists, Cambridge, England, p. $189-211$ ).

Cited under 'Hydrothermal systems/hydrothermal modeling'.

U.S. Geological Survey, 1986, Hawail Volcanoes National Park and vicinity 1:100,000-scale topographic map, 19155-D3-PF-100.

Cited under 'Geophysics/other'.

U.S. Geological Survey, 1992, Water resources data Hawali and other Paclfic areas, water year 1991. Volume 1. Hawa11: U.S. Geological Survey Water-Data Report HI-91-1, 282 p. Cited under 'Surface-water hydrology' and 'Water quality'.

Voss, C.I., and Souza, W.R., 1987, Variable density flow and solute transport simulation of regional aquifers containing a narrow freshwater-saltwater transition zone: Water Resources Research, v. 23, p. $1,851-1,866$. Cited under 'Permeability'.

Williams, J.A., and Soroos, R.L., 1973, Evaluation of methods of pumping test analysis for application to Hawailan aquifers: Water Resources Research Center Technical Report 20, University of Hawa11, Honolulu, $159 \mathrm{p}$.

Cited under 'Permeability'. 

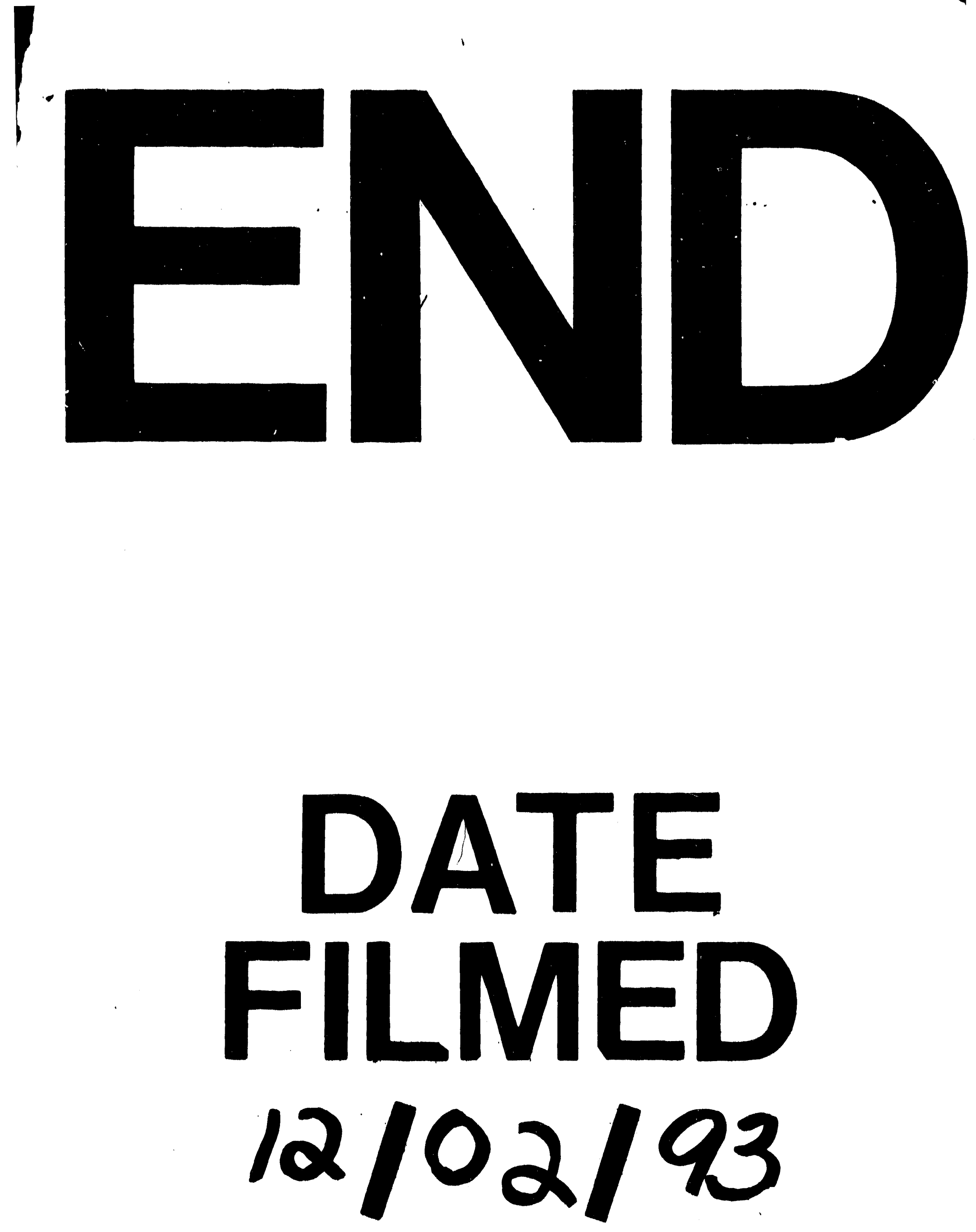